\title{
FUTURE ARCHITECTURE, ANCIENT WISDOM: ADAPTABLE STRUCTURES FROM ARCTIC TRADITION
}

\author{
N.P. MACKIN \\ University of Victoria and Mackin Tanaka Architecture, Canada.
}

\begin{abstract}
In the Canadian high Arctic, subsistence hunters and fishers have learned, over generations, to construct shelters from available materials so they can survive inclement weather while harvesting food. Now, as accelerating climate change exacerbates the intensity and unpredictability of extreme weather, scientists and country food harvesters once again worry about becoming stranded. To envision how tradition-based dwellings might serve as modern short-term survival/emergency structures, we reconstructed four vernacular structures in largely- Indigenous Arctic communities and compared them with a Sami reconstruction from Arctic Scandinavia. Local knowledge-holders and students participated and proposed adaptations using modern materials and concepts. The five structures were qualitatively evaluated for replicability, adaptability to modern situations, on-going usefulness, thermal performance, and materials availability. Quantitative evaluations included speed of construction relative to length of use and approximate mass of structure per person. The structures that were most adaptable, replicable, and efficient were elliptic paraboloid-shaped dwellings: Inuvialuit willow-framed moss-and-skin-clad dwellings (Western Canadian Arctic), Inuinnaqtun snow houses (iglus and qarmaqs) (central Canadian high Arctic), and birch-framed turf-clad homes (Scandinavian Arctic). All shared the following characteristics: (1) catenary- or elliptic paraboloid-domed framework, (2) materials accessed from immediate vicinity of building site, (3) ease of construction by 1 or few people, (4) passive heating and insulated assemblies, (5) windbreaks incorporated into siting and design, (6) strong structure resistant to high winds and inclement weather, and (7) siting along routes where foods are harvested. These characteristics are now serving as design principles for temporary Arctic dwellings, demonstrating how recording, adapting, and sharing long-resident peoples' architectural knowledge facilitates survival during extreme events associated with accelerated climate change.
\end{abstract}

Keywords: arctic indigenous knowledge, catenary arch, elliptic paraboloid, survival structures, vernacular architecture.

\section{INTRODUCTION}

Temporary, rapidly-built shelters have always been part of life in the high Arctic, where sudden storms and extreme cold pose serious risks to food harvesters, scientists, and other people out on the land. Safety concerns have intensified in recent times, as accelerated climate change brings increasingly unpredictable conditions. Fortunately, peoples of the far north have long traditions of temporary shelter-building. Because communities are often isolated and availability of purchased foods is limited, northern peoples continue to harvest foods from the land, for which they require wind-and cold-resistant shelters in most, if not all, seasons. Whether hunting seal or caribou, fishing for Arctic char, or gathering permafrost berries, families may spontaneously need a place to reside overnight or to keep less-mobile family members safe and warm. To make a shelter, harvesters would need to know: what construction materials are available? Can they be reused? How should the materials be assembled? What is the best site? Indigenous peoples of the north traditionally make such decisions depending on the time of year, materials availability, and location. Generations of architectural wisdom and practice facilitate answers to these questions $[1,2]$.

To document architectural wisdom of northern long-resident and Indigenous peoples, this research undertook modeling and full-scale reconstructions of tradition-based 


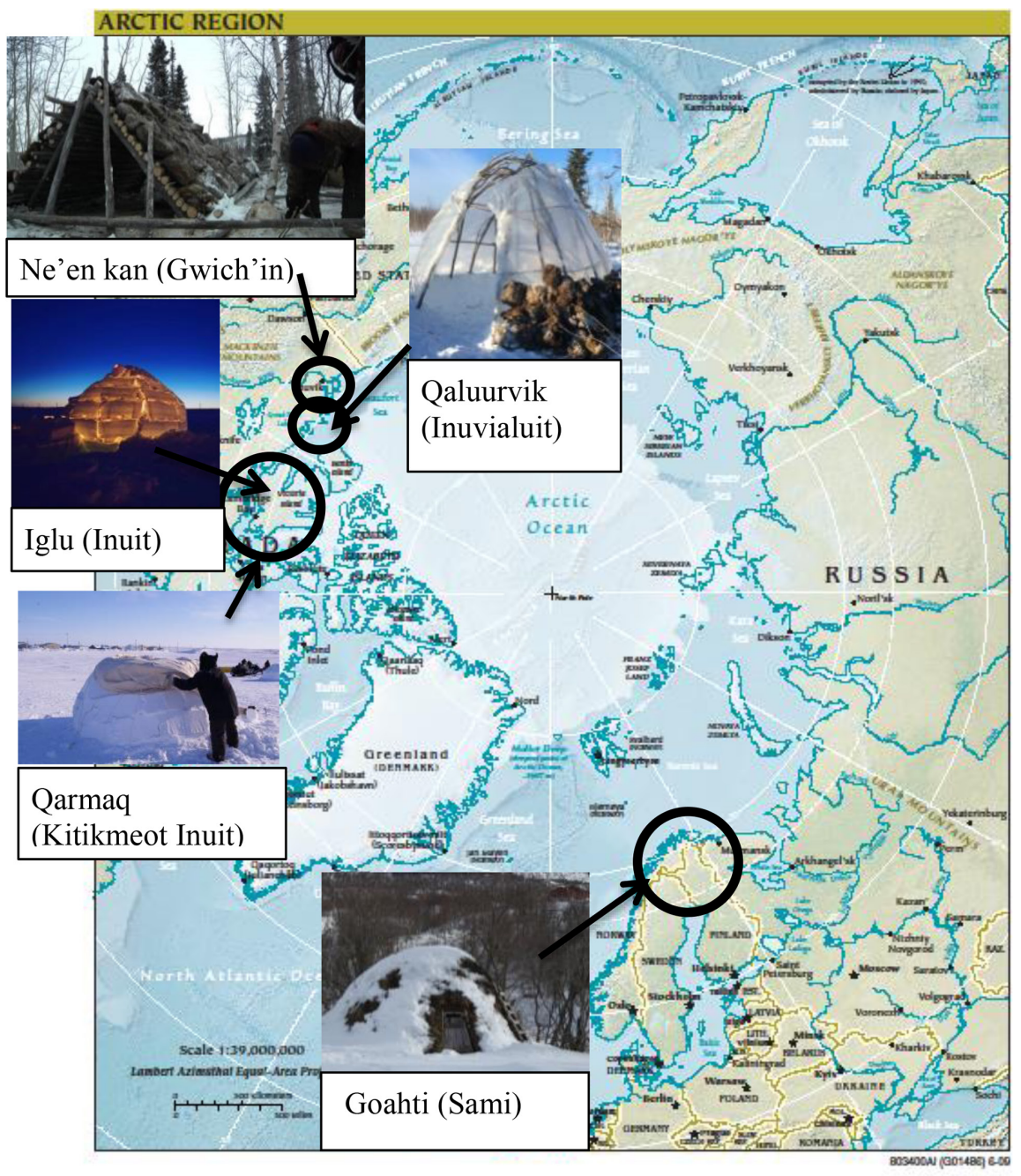

Figure 1: Showing reconstructions and associated regions. Photographs by the author.

temporary structures among Canadian Inuit (Inuit means 'people' in Arctic North America), First Nations people (non-Inuit Native North Americans such as Gwich'in), and Sami (Indigenous peoples of Northern Scandinavia) in four culturally- and geographically-distinct regions of the circumpolar north (Fig. 1). The structures were compared and analyzed for their efficiency, functionality, usefulness, and adaptability to present and future situations.

\section{METHOD: THE RECONSTRUCTIONS}

The idea for this research in adaptable shelters of Indigenous tradition began in 2009 in northern Norway. From a northern Canadian perspective, it was interesting to note architectural similarities across the North Pole. While working on an architectural site at the Riddu 
Riddu Festival of Indigenous Peoples in Manndalen, Norway, on the fjord in Kåfjorden $\left(69^{\circ} \mathrm{N} 20^{\circ} \mathrm{E}\right)$, it was noted that the reconstructed Sami turf house (goahti, sometimes called bealljegoahti) has an iglu-like form resulting from a framework of birchwood bent over by heavy snow. Over the framework, a layer of vertically-aligned birch poles supports overlapping sheets of birchbark (waterproofing) followed by turf blocks that provided insulation. Goahti would become stronger over time, since the turf blocks, which are stacked in bricklike formation, gradually grow over and become a continuous layer that is as much as 0.9 $\mathrm{m}(3 \mathrm{ft})$ thick at the base. As the turf settles and grows together, the finished goahti shape resembles a catenary dome $[3,4]$, the curve of natural load transfer in an arched formation [5]. Until the Second World War, goahti served as dwellings that lasted approximately 10 years [3].

Similar uses of turf and/ or moss for insulating and cladding temporary dwellings were noted in northern Canada, near the confluence of the Mackenzie River delta and the Beaufort Sea (Inuvik region, $68^{\circ} \mathrm{N}$ and $134^{\circ} \mathrm{W}$ ). As with the Riddu Riddu festival site, stunted trees are able to grow near Inuvik because the nearby waterways moderate temperatures. In this region, moss-clad dwellings called ne'en kan were traditionally built from a birch A-frame clad with blocks of stacked mossy turf, and were sometimes constructed by women of the Gwich'in First Nations [6]. A ne'en kan, built in 1995 by archeologist Jean-Luc Pilon and Gwich'in knowledge-holder Willie Simon, formed the basis of a reconstruction undertaken in November 2013 with the assistance of eight local high school students.

A year later, students and Willie Simon helped construct another moss-clad structure called a qaluurvik, a catenary dome-shaped dwelling framed with bent-and-tied willow. Then 92-year-old Inuvialuit Elder Persis Gruben from Aklavik $\left(68^{\circ} \mathrm{N}\right.$ and $\left.135^{\circ} \mathrm{W}\right)$ recalled qaluurvik construction from her childhood: "They were meant to be temporary, but we ended up living there for a long time" [7].

The final two reconstructions, a catenary-domed snow iglu and a qarmaq (spring iglu, a truncated catenary dome with driftwood-and-skin-roof) required the most skill. In in Cambridge Bay, NU, Canada, far above the tree line $\left(69^{\circ} \mathrm{N}\right.$ and $\left.105^{\circ} \mathrm{W}\right)$, a large iglu (12' diameter) was attempted in November 2015 by Inuit Elders and townspeople. Because the form and construction technique were not perfect, the iglu could not be completed. In April 2016, Inuk knowledge-holder Attima Hadlari was engaged to construct a winter iglu and a spring iglu in Cambridge Bay.

For each of the five reconstructions, Elders and knowledge-holders from each community contributed adaptation ideas. Architectural drawings were completed and measurements taken to facilitate quantitative analysis.

\section{EVALUATING THE STRUCTURES FOR USE AS ARCTIC WINTER SHELTERS}

Tables 1 and 2 compare characteristics of the Canadian Arctic reconstructions and the Sami goahti. Analysis confirmed that the A-framed ne'en kan required a considerable investment in sizeable birchwood, which would not be available in areas of the Arctic where lumber of those dimensions was available only as driftwood or by trade/purchase. Further, the ne'en kan was difficult to keep warm in winter, as it was generally open on one end. The ridge proved difficult to waterproof and melting snow leaked inside. Elders explained that ne'en kan was most useful in fall $[8,9]$.

The qarmaq was traditionally constructed in spring after rising outdoor temperatures and the reappearance of the sun caused the snow iglu roofs to melt and drip. Like the ne'en 
kan, the qarmaq was used for a short time relative to the number of hours required for construction. However, qarmaq are valued as emergency shelters because of their adaptability to Arctic spring weather [1].

Form and materials of the four domed (or partly domed) structures (goahti, qaluurvik, iglu, and qarmaq) are compared in Tables 2 and 3. To facilitate comparison, each reconstruction had a circular floor plan measuring 11'-2" (3.4 m) diameter on the interior face, with a floor

Table 1: Comparing efficiency of Arctic shelters.

\begin{tabular}{|c|c|c|c|c|}
\hline $\begin{array}{l}\text { Dwelling for family of } \\
4 \text { or } 5\end{array}$ & $\begin{array}{l}\text { Man } \\
\text { hours to } \\
\text { build }\end{array}$ & $\begin{array}{l}\text { Number of } \\
\text { months } \\
\text { used }\end{array}$ & $\begin{array}{l}\text { Hours to build/ } \\
\text { duration of use }\end{array}$ & $\begin{array}{l}\text { Approx. mass } \\
\text { of materials }\end{array}$ \\
\hline Ne'en kan & 128 & $\begin{array}{l}4 \text { per year, } 2 \\
\text { years }=8\end{array}$ & 16 & $7500 \mathrm{lb}$ \\
\hline Qaluurvik & 48 & 110 & 0.44 & $2800 \mathrm{lb}$ \\
\hline Iglu & 5 & 7 & 0.7 & $2500 \mathrm{lb}$ \\
\hline Qarmaq & 5 & 2 & 2.5 & $2100 \mathrm{lb}$ \\
\hline Goahti & 120 & 120 & 1 & 8400 lb. \\
\hline
\end{tabular}

Table 2: Qualitative comparison of Arctic shelters.

\begin{tabular}{lllll}
\hline $\begin{array}{l}\text { Dwelling for family } \\
\text { of } 4 \text { or } 5\end{array}$ & $\begin{array}{l}\text { Ease of } \\
\text { construction, } \\
\text { replicability }\end{array}$ & $\begin{array}{l}\text { Adaptability } \\
\text { to modern } \\
\text { situations }\end{array}$ & $\begin{array}{l}\text { Thermal } \\
\text { performance }\end{array}$ & $\begin{array}{l}\text { Materials } \\
\text { availability }\end{array}$ \\
\hline Ne'en kan & $\begin{array}{l}\text { Easy to build, } \\
\text { main wood } \\
\text { components } \\
\text { relatively } \\
\text { heavy but other } \\
\text { materials light }\end{array}$ & $\begin{array}{l}\text { Reasonable } \\
\text { emergency } \\
\text { shelter in } \\
\text { summer, } \\
\text { autumn }\end{array}$ & $\begin{array}{l}\text { Heated by fire } \\
\text { near open end } \\
\text { of structure, } \\
\text { not good in } \\
\text { extreme } \\
\text { temperatures }\end{array}$ & $\begin{array}{l}\text { caliper } \\
\text { birch only } \\
\text { found in } \\
\text { warmest } \\
\text { regions of } \\
\text { Arctic }\end{array}$ \\
\hline
\end{tabular}




\begin{tabular}{|c|c|c|c|c|}
\hline $\begin{array}{l}\text { Dwelling for family } \\
\text { of } 4 \text { or } 5\end{array}$ & $\begin{array}{l}\text { Ease of } \\
\text { construction, } \\
\text { replicability }\end{array}$ & $\begin{array}{l}\text { Adaptability } \\
\text { to modern } \\
\text { situations }\end{array}$ & $\begin{array}{l}\text { Thermal } \\
\text { performance }\end{array}$ & $\begin{array}{l}\text { Materials } \\
\text { availability }\end{array}$ \\
\hline Qaluurvik & $\begin{array}{l}\text { Easy to build } \\
\text { and replicate }\end{array}$ & $\begin{array}{l}\text { Excellent } \\
\text { emergency } \\
\text { shelter, modifi- } \\
\text { able with mod- } \\
\text { ern materials }\end{array}$ & $\begin{array}{l}\text { Excellent when } \\
\text { clad in skins, } \\
\text { then moss, } \\
\text { then outer } \\
\text { layer of skins, } \\
\text { with cover of } \\
\text { skins over the } \\
\text { entry }\end{array}$ & $\begin{array}{l}\text { materials } \\
\text { are light and } \\
\text { abundant } \\
\text { in Arctic } \\
\text { where wil- } \\
\text { low grows }\end{array}$ \\
\hline Iglu & $\begin{array}{l}\text { requires skill to } \\
\text { correctly spiral } \\
\text { the blocks, } \\
\text { built rapidly by } \\
\text { skilled builders }\end{array}$ & $\begin{array}{l}\text { Excellent } \\
\text { emergency } \\
\text { shelter when } \\
\text { snow is only } \\
\text { material avail- } \\
\text { able }\end{array}$ & $\begin{array}{l}\text { Very good in- } \\
\text { sulation when } \\
\text { heated im- } \\
\text { mediately after } \\
\text { construction }\end{array}$ & $\begin{array}{l}\text { Readily } \\
\text { available, } \\
\text { Requires } \\
\text { consistent } \\
\text { snow from a } \\
\text { single storm }\end{array}$ \\
\hline Qarma & $\begin{array}{l}\text { slightly easier } \\
\text { than the iglu } \\
\text { because the top } \\
\text { blocks are not } \\
\text { needed }\end{array}$ & $\begin{array}{l}\text { Excellent } \\
\text { emergency } \\
\text { shelter in } \\
\text { spring in areas } \\
\text { where trees do } \\
\text { not grow }\end{array}$ & $\begin{array}{l}\text { Good insula- } \\
\text { tion: drier than } \\
\text { iglu once the } \\
\text { sun reappears } \\
\text { and melts } \\
\text { snow }\end{array}$ & $\begin{array}{l}\text { See iglu. } \\
\text { needs } \\
\text { driftwood } \\
\text { or bones to } \\
\text { support skin } \\
\text { roof }\end{array}$ \\
\hline $\begin{array}{l}\text { Goahti (Sami Turf } \\
\text { house) }\end{array}$ & $\begin{array}{l}\text { Wood assem- } \\
\text { bly requires } \\
\text { skill. } \\
\text { Birchbark } \\
\text { removal and } \\
\text { installation } \\
\text { requires skill. } \\
\text { Replicable } \\
\text { with knowl- } \\
\text { edge }\end{array}$ & $\begin{array}{l}\text { Good shelter, } \\
\text { considerable } \\
\text { manpower } \\
\text { and wood } \\
\text { required }\end{array}$ & $\begin{array}{l}\text { Excellent } \\
\text { insulation and } \\
\text { waterproofing } \\
\text { for year-round } \\
\text { occupancy }\end{array}$ & $\begin{array}{l}\text { Curved } \\
\text { birch trees } \\
\text { rare; needs } \\
\text { about } 20 \\
\text { small trees, } \\
\text { with bark } \\
\text { carefully } \\
\text { removed. }\end{array}$ \\
\hline
\end{tabular}

area of $97.63 \mathrm{ft}^{2}\left(9.07 \mathrm{~m}^{2}\right)$. For Inuit from the Cambridge Bay area, $1.8 \mathrm{~m}^{2}$ per person was recorded as an average number of occupants in an iglu [10]. Accordingly, each dwelling listed below is assumed to accommodate two adults and 2 or 3 children. Although the heights of structures tend to vary somewhat, the average volume of each dwelling was approximately $570 \mathrm{ft}^{3}\left(16.14 \mathrm{~m}^{3}\right)$. 
Table 3: Images and drawings of adaptable winter shelters (photos E. Hadlari and N. Mackin, drawings N. Mackin).

Type and images : looking upwards to the roof, and construction photos or sketches

Plan and section, and proposed adaptations

Iglu (snow house)
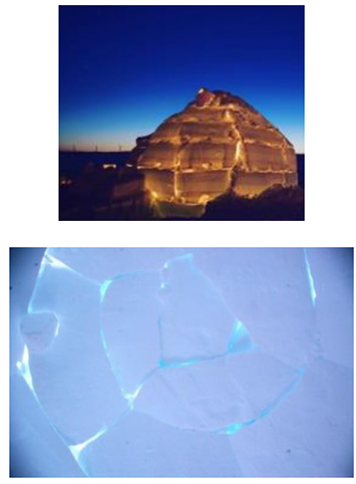

Qarmaq (spring snow house)

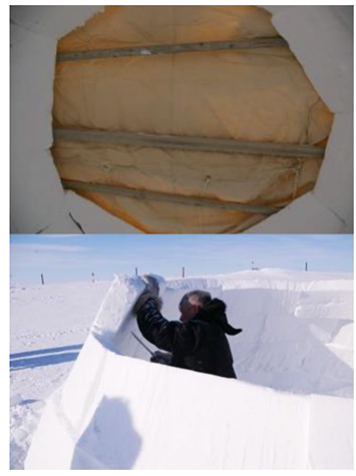

Qaluurvik (moss/willow)

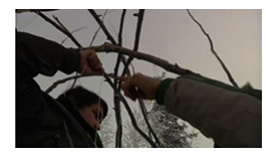

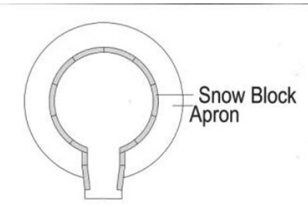

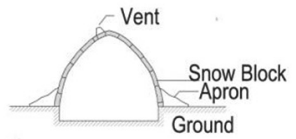

Adaptation: present day Inuit heat their iglus with propane stove instead of traditional seal oil lamp

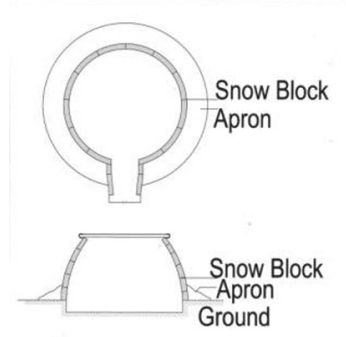

Adaptation: propane stove, use of tarps along with skins for roof, use of string to fasten roof instead of traditional snow blocks

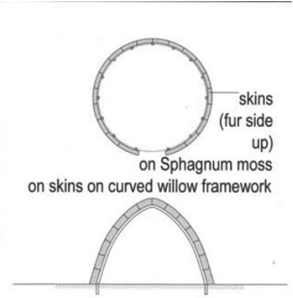

Adaptation: tarps were tried instead of skins for waterproofing. Clear tarps help retain solar heat when the sun reappears 
Type and images : looking upwards to the roof, and construction photos or sketches

Plan and section, and proposed adaptations
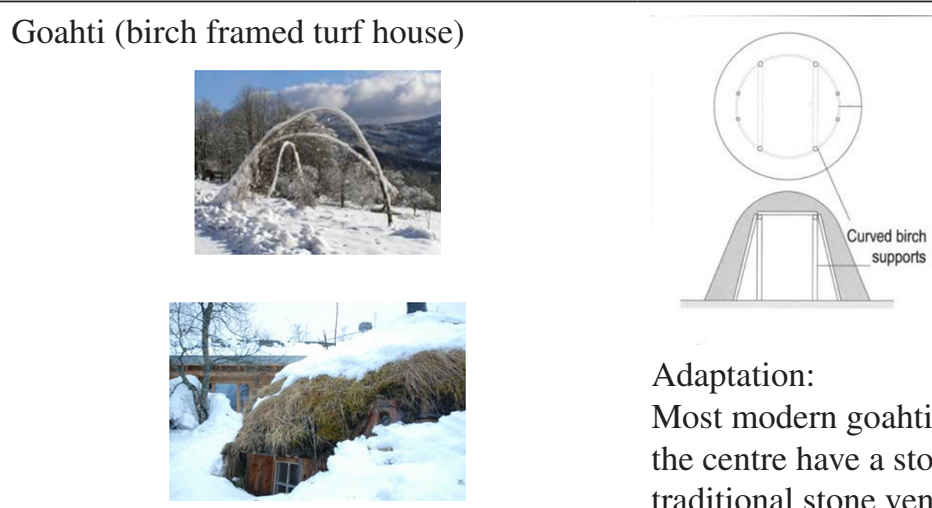

Adaptation:

Most modern goahti with a fireplace in the centre have a stovepipe rather than the traditional stone vent built at the base of one wall. Modern windows and doors may be used

(photo below: goahti reconstruction at University of Troms $\varnothing$ )

\section{SHARED CHARACTERISTICS AMONG SELECTED VERNACULAR SHORT-TERM DWELLINGS OF THE CIRCUMPOLAR NORTH}

Numerous similarities emerge when examining characteristics of high Arctic dwellings adaptable as modern shelters:

(a) FORM. The four domed dwellings exhibit one of the strongest and most stable forms in nature, the catenary dome, seen in its purest form in the iglu [11, 12]. If the iglu is built any way other than as a catenary dome, and other than with the characteristic spiraling of the snow blocks, it fails $[1,11,12]$. By contrast, the A-framed ne'en kan is inherently unstable as the frame has a tendency to kick outward at the base. To counteract this instability, the ne'en kan was braced against several live birch trees, which prevented the base logs from splaying outwards. The qaluurvik employs less material and is faster to build than the ne'en kan, yet results in a much stronger form [13] that would last years under heavy snow and wind loading [7, 14].

(b) LOCAL MATERIALS: Use of materials accessed from immediate vicinity of building site is a characteristic of most vernacular dwellings, including structures recreated in this research. Sites above the treeline, like Cambridge Bay offer few winter materials, as even large rocks are buried in snow. For the iglu and qarmaq, the snow must be tested to make sure it is of an even consistency and the right density $[1,11]$.

(c) BUILT BY ONE OR FEW PEOPLE: As shown in Table 1, the ne'en kan required the most people and man hours. The qaluurvik took the least man hours to build per month of use, with the iglu second and the goahti a close third.

(d) PASSIVE HEATING AND INSULATED ASSEMBLIES: Well-insulated structures are keys to survival in the Arctic, and are also useful in other places of the world. Moss, turf, and snow are all good insulators. Depending on surface area to volume ratios, snow iglus, heated with one seal oil lamp, are as much as $45^{\circ} \mathrm{C}$. warmer inside than outside [11]. Other passive heating strategies include: minimizing heat loss through ventilation open- 


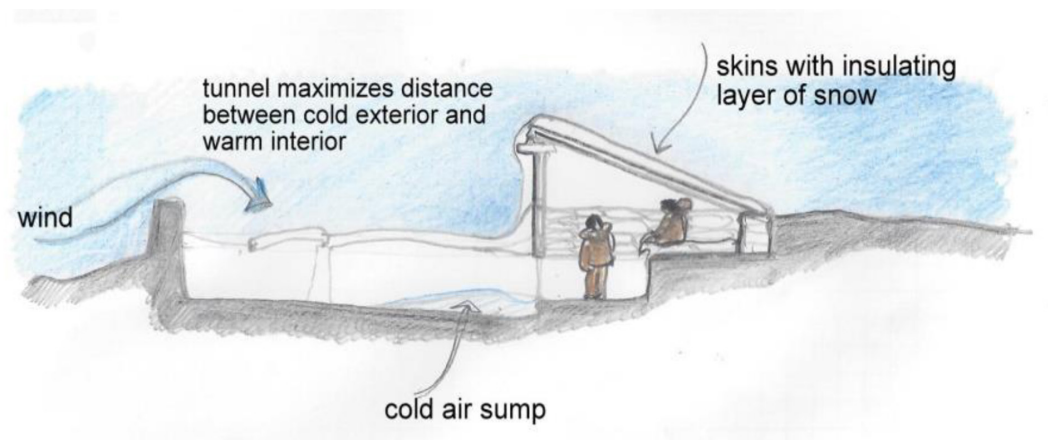

Figure 2: Sketch of passive heating technologies in Inuit traditional dwelling.

ings, long entry vestibules, and employing levels so the warmest areas are those used by people for sleeping or activities requiring bare hands and dexterity.

(e) WINDBREAKS AS PART OF SITING AND DESIGN: entrances are protected by some form of windbreak, either constructed (see Fig. 2) or by selecting a site in the lee of a hill or other natural protection $[1,8,14]$.

(f) STRONG STRUCTURE RESISTANT TO HIGH WINDS: As described in (a) above, the catenary dome-shaped buildings possess strength, particularly when reinforced horizontally. The qaluurvik was reinforced at about mid-way up the structure with horizontal willow withes; this resulted in a rigid and sturdy yet light structure [7, 14]. The iglu and qarmaq have snow aprons at the base that strengthen the block structure where it is weakest, near where the ground [10].

(g) SITING ALONG ROUTES WHERE FOOD IS HARVESTED: choosing a site for a structure is crucial: unless stranded, Indigenous peoples of the Arctic would never build where there is no food $[1,8]$.

\section{APPLICATIONS}

When identifying which qualities of each of the Arctic winter-suited traditional shelters contribute towards an ideal, adaptable shelter for the future, it is recognized that most dwellings from the past have characteristics that do not necessarily suit modern lifeways. Nonetheless, adapting tradition-based or vernacular architectural ideas for modern needs is a time-honored design process $[4,15]$. Further, adapting vernacular architectural concepts and forms as emergency shelters has on-going importance, particularly in areas of extreme weather such as the high Arctic.

As of 2016, direct applications for tradition-based Arctic structures have emerged. The Canadian Center for High Arctic Research, centered in Cambridge Bay NU, is interested in the life-saving potential of iglus and other tradition-based shelters, as their scientists head out into places where extreme weather can foil rescues. Food harvesters, including families, find themselves stranded and sometimes the Canadian Coast Guard cannot reach them by ship or helicopter. Impromptu-built iglus or qaluurviks (in areas where willow grows) would help people stay safe until help arrived. Temporary shelters are needed increase comfort, too. Fishers and hunters in the Inuvik region noted that learning to build a qaluurvik could be just the solution they need for winter nights of ice fishing (Fig. 3). (A manual of vernacular Canadian Arctic dwellings, adapted for the present and future, is a final component of this research and will serve as part of northern communities' strategies for climate change adaptation.) 


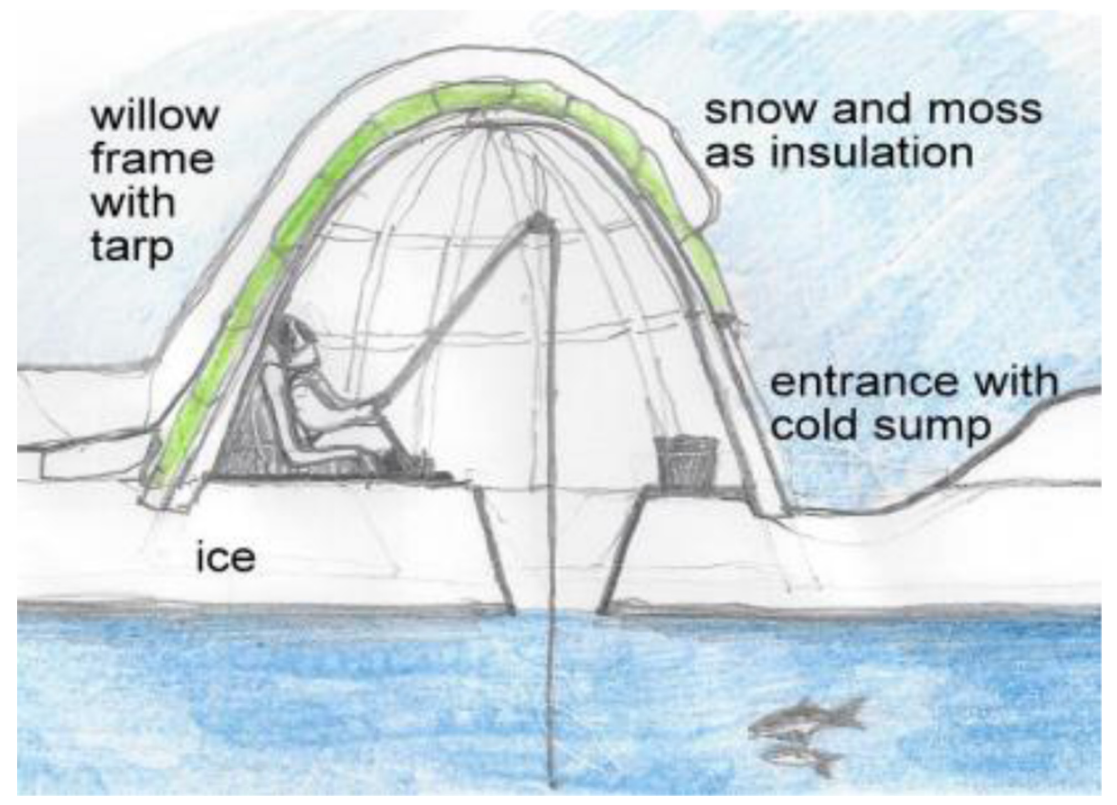

Figure 3: Proposed ice fishing hut based on qaluurvik.

By contrast, curved birch goahti (bealljegoahti) are semi-permanent dwellings that might take too long to build to be useful for emergency survival. However, a simpler stacked turf house could be built in a day [4] and would facilitate unexpected overnight stays on the land. Goahti are useful in other ways, too: they become places for ceremony and story-telling, as with the reconstructions at Riddu Riddu and the University of Troms $\varnothing$.

Close relationships between peoples of the far north and the natural world facilitated vernacular designs of buildings that resist cold and wind, using materials found in the immediate vicinity $[1-4,14]$. Architectural ideas stemming from a place-based, nature-aware approach typically conserve materials by utilizing them with optimal shapes and function. Such vernacular architectural ideas may employ elements of biomimicry (i.e. materials, designs, and systems that are modeled on biological processes and entities) but with an added component of long-resident peoples' cultural knowledge (sometimes referred to as Traditional Ecological Knowledge, or TEK). Using principles of culturally-informed biomimicry, Western science might look into fabricating a material that mimics the properties of sphagnum moss: a good insulator that also becomes a waterproofing layer when it grows together as a thick mat, and even acts as a carbon sink to help mitigate climate change. Similarly, birchbark might inspire a biodegradable, non-plastic, breathable waterproofing layer for the future, using a material that is presently discarded by sawmills. In addition, the catenary arch form is recognized by vernacular and academic architecture/ engineering alike as an ideal form found in nature [10-13].

Passive heating technologies are other attributes of Arctic vernacular structures that translate directly into modern adaptable/temporary structures. Linking architecture with food production is another concept useful for temporary - and possibly permanent - structures of the future.

Long resident peoples such as Gwich'in, Inuvialuit, Copper Inuit, and Sami have learned over countless generations of observation and experimentation to construct place-specific, 
biomimetic architecture that can selectively inform adaptable architecture of the future. Siting, materials, forms, assembly technologies, and other considerations from the architecture of Arctic Indigenous peoples provide a valuable resource for designers of adaptable, temporary, and emergency shelters now and into the future.

\section{ACKNOWLEDGEMENTS}

I gratefully acknowledge funding from Health Canada's Climate Change and Health Adaptation Program for Northern First Nations and Inuit Communities. Thank you to the knowledge-holders who assisted with this research, including Attima Hadlari, Elisabeth Hadlari, Willy Simon, Mabel English, John Jerome, and videographers Mark Hadlari and Dennis Allen.

\section{REFERENCES}

[1] Hadlari, A., Personal communication, April 7-9 2016, Inuit knowledge-holder, Cambridge Bay NU Canada.

[2] Mackin, N., Moss houses in the circumpolar north: architectural traditions and innovations that respond to climate change. International Journal of Climate Change: Impacts and Responses, 8(2), pp. 1-14, 2015.

[3] Emmons, R., An investigation of sami building structures. Sami Culture, University of Texas, available at: https://www.laits.utexas.edu/sami/dieda/anthro/architecture. htm\#Thermal, 2004.

[4] Sjølie, R., The sami goahti, an earthen house in the arctic. Vernacular Architecture and Earthen Architecture: Contribution for Sustainable Architecture, The Sami Goahti, an Earthen House in the Arctic, Taylor and Francis Group: London, pp. 71-76, 2014.

[5] Auroville Earth Institute UNESCO Chair Earthen Architecture, Stability Notions, available at: http://www.earth-auroville.com/stability_notions_en.php

[6] Fehr, A. \&Andre, A., Gwich'in Ethnobotany, Gwich'in Social and Cultural Institute and Aurora Research Institute: Inuvik NWT Canada, 2002.

[7] Gruben, P., Personal Communication, Inuvialuit Knowledge-Holder, Dec. 18, Aklavik NWT Canada.

[8] English, M., Personal communication, Inuivialuit knowledge-holder, Dec. 2015, Inuvik NWT Canada.

[9] Jerome, J., Personal communication, Inuivialuit knowledge-holder, Dec. 2015, Inuvik NWT Canada.

[10] Lee, M. \& Reinhardt, G.T., Eskimo Architecture: Dwelling and Structure in the Early Historic Period, University of Alaska Press: Fairbanks AK, 2002.

[11] Peter Kershaw, G., Scott, P.A. \& Welch, H.E., The shelter characteristics of traditionalstyled inuit snow houses. Arctic, 49(4), pp. 328-338, 1996.

http://dx.doi.org/10.14430/arctic1208

[12] Handy, R.L., The perfect dome. American Scientist May-June 2011, available at: http:// www.americanscientist.org/issues/pub/2011/3/the-perfect-dome

[13] Monreal, A., Catenary or Parabola, who will tell? DIMACS entre for Discrete mathematics and theoretical computer science, available at: http://www.cs.rutgers.edu/ mcgrew/ dimacs/slides/Amadeo_Huylebrouck.pdf

[14] Inuvialuit Elders with Robert Bandringa, Inuvialuit Nautchiangit: Relationships between people and plants, Inuvik: Inuvialuit Cultural Resource Centre, 2010.

[15] Senosiain, J., Bio-architecture, Architectural Press: Oxford, 2003. 